\title{
Calcium binding and concomitant changes in the structure and heat stability of calprotectin (L1 protein)
}

\author{
C F Naess-Andresen, B Egelandsdal, M K Fagerhol
}

\begin{abstract}
Aim-To obtain further data on the structure and conformation of calprotectin, a prominent leucocyte protein found in many species.

Methods-The binding of $\mathrm{Ca}^{2+}$ to calprotectin was studied by means of equilibrium dialysis using ${ }^{45} \mathrm{Ca}$ as tracer. The thermal stability and denaturation kinetics of calprotectin were studied by means of differential scanning calorimetry. Concomitant alterations in optical activity resulting from different conditions were measured. A computer program calculated the parameters to fit different models of protein structure. Ultraviolet spectroscopy gave absorbtion spectra. Sedimentation velocity studies and molecular weight determinations by the low speed (sedimentation) equilibrium technique were performed.
\end{abstract}

Results-A maximum of six calcium ions were bound per calprotectin molecule at $0.7 \mathrm{mM}$ calcium chloride. The apparent dissociation constants were calculated. perature by $26^{\circ} \mathrm{K}$. The enthalpy of denaturation was also increased by $\mathrm{Ca}^{2+}$. Addition of $\mathrm{Ca}^{2+}$ to the buffers caused a gradual change in the near UV circular dichroism spectrum, while only minor changes were seen at wavelengths of 210-240 nm. A gradual increase in the sedimentation coefficient was observed on addition of calcium chloride. The extinction coefficient at $279 \mathrm{~nm}$ was determined: $E_{279}=2 \cdot 53 \cdot 10^{4} \mathrm{M}^{-1} \mathrm{~cm}^{-1}$.

Conclusions-Calprotectin can bind six calcium ions. Upon binding, the protein shows distinct conformational changes and increased thermal stability. The former may be of importance for its function, while the biological significance of the latter is unknown.

(f Clin Pathol: Mol Pathol 1995;48:M278-M284)

Keywords: Calcium binding, calprotectin, heat stability.

Norwegian Food Research Institute, Department of Analytical Methods, N-1432 As-NLH, Norway

B Egelandsdal

Correspondence to: Dr Naess-Andresen.

Accepted for publication 20 June 1995.

The name calprotectin ${ }^{1}$ has recently been applied to the human leucocyte protein previously called $\mathrm{L} 1,{ }^{2}$ an abbreviation which will be used here. Early studies ${ }^{3}$ suggested that L1 binds calcium. In recent years, it has become evident that the protein contains two types of poly$\mathrm{Ca}^{2+}$ ions increased the denaturation tem-

peptide chain ${ }^{45}$ with molecular weights of about 8 and $14 \mathrm{kDa}$. The intact protein consists of two heavy chains $\left(\mathrm{Ll}_{\mathrm{H}}\right)$ and one light chain $\left(\mathrm{Ll}_{\mathrm{L}}\right)$. The molecular mass of $\mathrm{L1}$ in both leucocytes and plasma is about $36.5 \mathrm{kDa}$ unless denaturating agents are used. ${ }^{67}$ Their amino acid sequencies have been determined, ${ }^{4}$ and each contains one classical and one modified calcium binding EF-hand. ${ }^{58}$

On the basis of the amino acid sequences derived from cDNA studies ${ }^{5}$ the molecular weights of the light and heavy chains can be calculated to be 10835 and $13242 \mathrm{Da}$ respectively, ignoring post-translational modifications. Applying SDS-PAGE, different investigators $^{59}$ have shown bands corresponding to the $\mathrm{L} 1$ light and heavy chains and called them MRP-8 and MRP-14, respectively. In the studies presented here we have used $36500 \mathrm{Da}$ for all calculations. There seem to be no covalent bonds between the chains, since reducing agents are not needed for dissociation. They can, however, be separated in 6-8 $\mathrm{M}$ urea. $^{\text {? }}$

L1 constitutes about $60 \%$ of the cytosol proteins or $5 \%$ of the total protein content in human neutrophil granulocytes and monocytes. ${ }^{2}$ It may also be found in smaller amounts in the plasma membrane and the nucleus. It is found in mucosal squamous epithelium, ${ }^{10}$ but not in epidermis, except in several inflammatory skin diseases. ${ }^{11}$ The protein is released from neutrophil granulocytes and monocytes during their activation or death, causing increased extracellular concentrations.

The plasma concentration of L1 may increase in various pathological conditions. In severe bacterial infections plasma L1 rises to 40-130 times the normal mean, while in viral infections normal or only slightly increased values are found. ${ }^{12}$ The normal plasma concentration is $50-910 \mu \mathrm{g} / 1$ (mean $530 \mu \mathrm{g} / \mathrm{l}$ ) for men and $80-880 \mu \mathrm{g} / \mathrm{l}$ (mean $440 \mu \mathrm{g} / \mathrm{l}$ ) for women.

Recently it has been shown that $\mathrm{L} 1$ was present in increased concentrations in stools from patients with colorectal cancer. A test for faecal L1 determination may possibly be used as a diagnostic tool for gastrointestinal diseases. ${ }^{13}$

The aim of the present study was to obtain further data on the structure and conformation of L1 which may contribute to a better understanding of the structure and biology of this protein. 


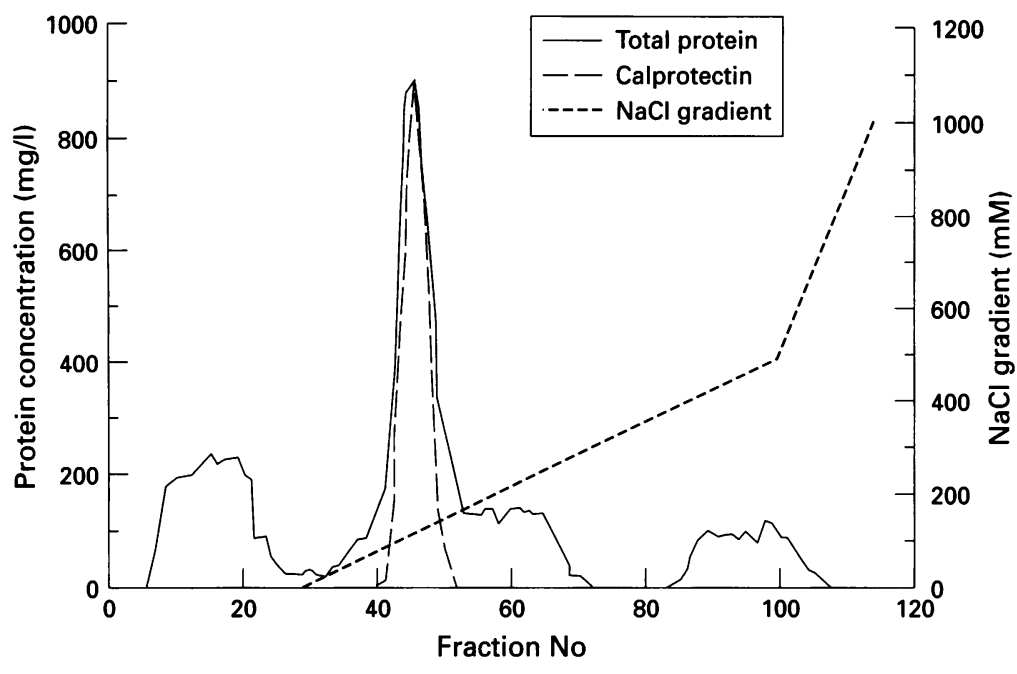

Figure 1 Elution profile of proteins from a DEAE-Sephacel ionic exchange column $(1.5 \times 10 \mathrm{~cm})$. The column was equilibrated with $20 \mathrm{mM}$ barbitone buffer added $0.5 \mathrm{mM}$ EDTAK, pH 8.5. L1 was eluted with a NaCl gradient $(0-1 \mathrm{M})$. Total protein was determined by the Bio-Rad method and the $L 1$ was determined by single radial immunodiffusion. The L1 protein appeared in fractions 40-50.

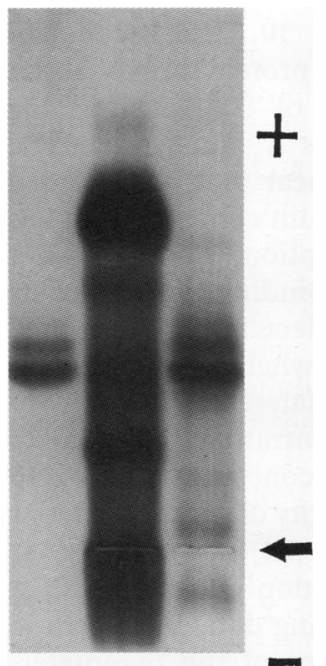

A B C

Figure 2 Agarose gel (1\% w/v) electrophoresis, the buffer containing $75 \mathrm{mM}$ barbitone/sodium barbitone, $2 \cdot 5 \mathrm{mM} \mathrm{EDTAK}_{2}$, and $0.2 \mathrm{mM}$ merthiolate, adjusted to $\mathrm{pH} 8 \cdot 6$. Coomassie blue stained, showing typical patterns of (A) purified L1, (B) normal serum, and $(C)$ crude leucocyte extract. The arrow indicates level of sample application.

\section{Methods}

BUFFERS AND SALT SOLUTIONS

For dialysis experiments, distilled deionised water (Levatitt S100 resin; Bayer) stored in polypropylene bottles was used. Tris-maleate buffers were prepared as described by Gomori. ${ }^{14}$ Appropriate amounts of analytic quality $\mathrm{Na}_{2} \mathrm{HPO}_{4}, \mathrm{CaCl}_{2}$, and $\mathrm{NaCl}$ were added to Tris- $\mathrm{HCl}$ buffers $(0 \cdot 1 \mathrm{M}, \mathrm{pH} 8 \cdot 1)$ for circular dichroism and differential scanning calorimetry (DSC) to obtain the required salt concentration and ionic strength.

PREPARATION OF CALPROTECTIN

Crude leucocyte extract ${ }^{3}$ was applied on a DEAE-Sephacel (Pharmacia) column $1.5 \times$ $10 \mathrm{~cm}$, equilibrated with $20 \mathrm{mM}$ barbitone buffer with $0.5 \mathrm{mM} \mathrm{EDTAK}_{2}, \mathrm{pH} 8.5$. L1 was eluted with a 0 to $1 \mathrm{M}$ sodium chloride gradient (see fig 1), concentrated by ultrafiltration using a Millipore ${ }^{\circledR}$ immersible-CX molecular separator, and finally run on an Ultrogel AcA 54 (LKB) column $2.5 \times 80 \mathrm{~cm}$, equilibrated with $50 \mathrm{mM}$ ammonium hydrogen carbonate buffer (pH 8.0). The L1 peak giving the typical bands on agarose gel electrophoresis purity test (see fig 2) was shell frozen, freeze dried, and stored in the cold until used. The quantification of L1 was done by single radial immunodiffusion as described earlier. ${ }^{3}$

Protein concentrations were determined by the Coomassie blue method using Bio-Rad protein assay kits.

\section{DIALYSING CELLS}

The dialysing cells used were made from acrylic, size $5 \mathrm{~cm} \times 5 \mathrm{~cm} \times 0.9 \mathrm{~cm}$. Each of the cylindrical dialysing chambers had a diameter of $1.9 \mathrm{~cm}$ and a depth of $0.5 \mathrm{~cm}$. The chambers were separated by a dialysing membrane. ${ }^{15}$ The dialysing membranes (Union Carbide) were stabilised by boiling with $1 \mathrm{mM}$ EDTA and rinsed thoroughly in distilled water before use. ${ }^{16}$
EQUILIBRIUM DIALYSIS

${ }^{45} \mathrm{Ca}$ was delivered as calcium chloride in aqueous solution from Amersham International. The tracer was added to give a specific activity of about $2.5 \mathrm{GBq} / \mathrm{mol} \mathrm{Ca}^{2+}$ in the test solutions. The radioactivity was assayed with a Wallac 81000 liquid scintillation counter. Samples of $50 \mu \mathrm{l}$ volume were dissolved in $5 \mathrm{ml}$ Opti-Flour scintillation fluid (Packard) and counted for 10 $\min$

The binding of $\mathrm{Ca}^{2+}$ to $\mathrm{Ll}$ was studied by means of equilibrium dialysis using ${ }^{45} \mathrm{Ca}$ as tracer. In preliminary experiments optimal binding was found at about $\mathrm{pH} 7$. Buffered protein solution $(250 \mu \mathrm{l})$ was instilled in one of the cell chambers and buffered solution of $\mathrm{CaCl}_{2}$ and tracer $(250 \mu \mathrm{l})$ in the other chamber. The cells were sealed and shaken at $25^{\circ} \mathrm{C}$ for $16 \mathrm{~h}$. Blank experiments showed that $16 \mathrm{~h}$ was sufficient time for $\mathrm{Ca}^{2+}$ to equilibrate in the cells. At the end of dialysis, samples from each chamber were counted.

The $\mathrm{Ca}^{2+}$ binding was investigated in two ways: (1) by keeping the L1 concentration constant at $0.02 \mathrm{mM}$ and varying the $\mathrm{Ca}^{2+}$ concentration ( $\operatorname{var} \mathrm{Ca}^{2+}$ ) between 0.01 and $1.0 \mathrm{mM}$, and (2) by keeping the $\mathrm{Ca}^{2+}$ concentration at $0.2 \mathrm{mM}$ while varying the $\mathrm{Ll}$ concentration (var L1) between 0.001 and $0.04 \mathrm{mM}$.

\section{DIFFERENTIAL SCANNING CALORIMETRY}

The thermal stability and denaturation kinetics of the L1 protein was studied with a PerkinElmer DSC-2 calorimeter equipped with an intracooler. The DSC data were recorded at each degree increment in temperature using a computer on line with the DSC instrument. The data were treated interactively as described by Harbitz et al. ${ }^{17}$ The baseline is subtracted empirically $^{17}$ as we used a calorimeter of intermediate sensitivity and therefore a high protein concentration.

Protein samples $(60 \mathrm{mg} / \mathrm{ml})$ were heated in aluminium pans $(15 \mathrm{ml})$ from $7^{\circ} \mathrm{C}$ to $100^{\circ} \mathrm{C}$ (heating rate $10^{\circ} \mathrm{C} / \mathrm{min}$ ). The protein samples were dissolved in Tris buffers with increasing calcium concentrations until the protein was saturated with $\mathrm{Ca}^{2+}$. Three measurements were recorded at each $\mathrm{Ca}^{2+}$ to protein ratio. No modelling of the thermogram shapes to obtain information about the number of domains ${ }^{18}$ was attempted as insufficient replicats were made to validate properly the fitting of such a model. Thus the number of peaks reported are those which seem plausible by visual inspection of the thermograms, an approach used in reports on the DSC technique. ${ }^{19}$ The temperature when denaturation of the protein starts, $T_{\text {onser }}$ and the temperature when the heat flow is maximal, $T_{\max }$, were determined with a standard error of $\pm 1.4^{\circ} \mathrm{C}$.

\section{CIRCULAR DICHROISM}

Alterations in optical activity under different conditions were measured with a Jobin-Yvon dichrograph IV connected to a computer. The computer was programmed to subtract the 

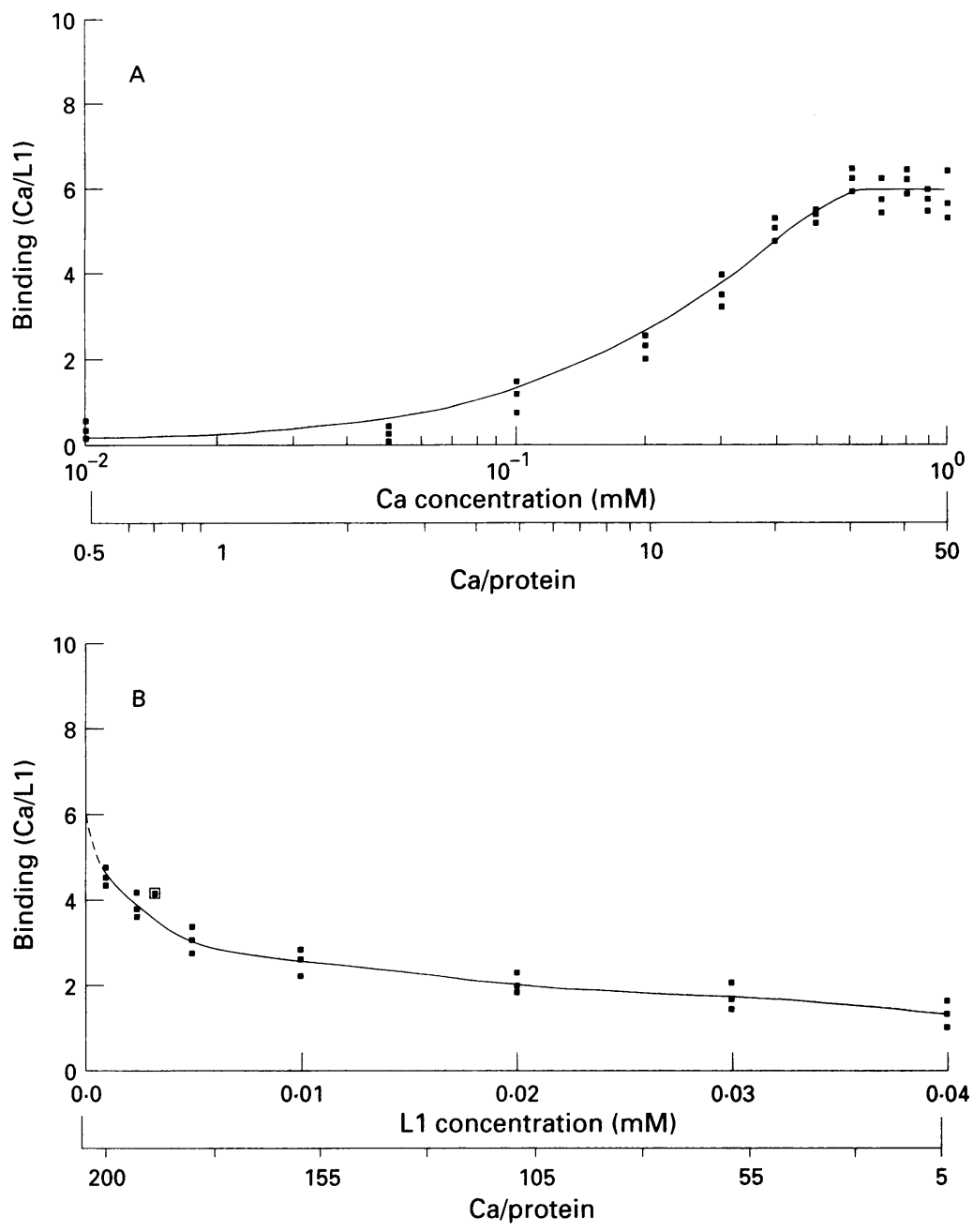

Figure 3 Number of calcium ions bound per L1 molecule. (A) Number of $\mathrm{Ca}^{2+}$ ions bound per molecule as a function of the concentration of calcium on a logarithmic scale. Aliquots of $\mathrm{Ca}^{2+}, 0.2 \mathrm{mM}$ including tracer, were dialysed against protein solutions. Concentrations varied from 0.001 to $0.04 \mathrm{mM}$. (B) Number of $\mathrm{Ca}^{2+}$ ions bound per molecule as a function of the concentration of L1 protein on a linear scale. Aliquots of L1 protein, $0.75 \mathrm{mg} / \mathrm{ml}$, were dialysed against $\mathrm{Ca}^{2+}$ solutions with ${ }^{45} \mathrm{Ca}$ as a tracer. Total $\mathrm{Ca}^{2+}$ varied from 0.01 to $1.0 \mathrm{mM}$. Dashed line indicates extrapolation. The samples in $(A)$ and $(B)$ were dialysed for $16 \mathrm{~h}$ at $25^{\circ} \mathrm{C}$ in Tris-maleate buffer, $p H 7$.

baseline from the sample signals and calculate parameters to fit different models of protein structure. The spectra were recorded eight times at a scan rate of $20 \mathrm{~nm} / \mathrm{min}$. Each spectrum was recorded two or three times on independently prepared solutions. The statistical mean is given. Protein solutions for circular dichroism recordings $(1.0 \mathrm{mg} / \mathrm{ml})$ were prepared in Tris buffers with calcium concentrations from 0 to $0.60 \mathrm{mM}$. The solutions were passed through $0.45 \mu \mathrm{m}$ filters before each run. Calibration of the dichrograph was performed periodically at $304 \mathrm{~nm}$ using epiandrosterone $(1.25 \mu \mathrm{g} / \mathrm{ml}$, Roussel UCLAF OF 0269) in dioxane according to the specifications given by the manufacturer. To check the instrument, the daily starting up procedure included recording the spectrum of a reference lysozyme solution and comparing the resulting spectrum with previously recorded spectra stored in the software. Aliquots of lysozyme standards (Sigma, catalogue No 6876) were stored in liquid nitrogen. For recordings in the far UV range $(185-265 \mathrm{~nm})$ the light path in the cell was $0.1 \mathrm{~mm}$; for the near UV $(250-350 \mathrm{~nm})$ it was $10 \mathrm{~mm}$. The recordings were carried out at ambient temperature.
ULTRAVIOLET SPECTROSCOPY

Recordings of UV absorption were made with a Beckman model 35 spectrophotometer connected to a Beckman chart recorder (Beckman Scientific Instrument Division). The protein $(1 \mathrm{mg} / \mathrm{ml})$ was dissolved in Tris buffer containing $1 \mathrm{mM} \mathrm{CaCl}{ }_{2}$. The lightpath in the quartz cells was $10 \mathrm{~mm}$. Scans were made from 360 to $200 \mathrm{~nm}$ using scan speed $100 \mathrm{~nm} / \mathrm{min}$.

\section{ANALYTICAL ULTRACENTRIFUGATION}

Sedimentation velocity studies were performed using a Beckman Spinco model E analytical ultracentrifuge equipped with Schlieren optical systems. A titanium rotor $(\mathrm{An}-\mathrm{H})$ and a cell with a single sector charcoal filled centrepiece were run at $60000 \mathrm{rpm}$ for $2 \mathrm{~h}$ at $20^{\circ} \mathrm{C}$. The cells were filled with $600 \mu \mathrm{l}$ Tris- $\mathrm{HCl}$ buffer $\mathrm{pH}$ 8.1 containing $5 \mathrm{mg}$ protein $/ \mathrm{ml}$ and different concentrations of $\mathrm{CaCl}_{2}$. Pictures were taken automatically every $32 \mathrm{~min}$ unless otherwise stated. Molecular weight determinations were made by the low speed (sedimentation) equilibrium technique: The centrifuge was operated at $14000 \mathrm{rpm}$, equilibrium was attained within $24 \mathrm{~h}$ in the cell with a liquid volume of $100 \mu \mathrm{l}$. The buffers and concentrations were identical to those in the sedimentation experiments.

\section{Results}

EQUILIBRIUM DIALYSIS

Figure 3A shows that the binding of $\mathrm{Ca}^{2+}$ to the protein increases with increasing concentration of the ligand, reaching a saturation value of six calcium ions per protein molecule at about $0.67 \mathrm{mM} \mathrm{Ca}^{2+}$, corresponding to a $\mathrm{Ca}^{2+}$ to protein ratio of 30 . The binding of $\mathrm{Ca}^{2+}$ started at a $\mathrm{Ca}^{2+}$ to protein ratio of about 5. Plotting the binding of $\mathrm{Ca}^{2+}$ against log $\mathrm{Ca}^{2+}$ concentration gives a non-symmetrical sigmoidal curve. The linear plot of occupied binding sites versus calcium concentration has the form of an adsorption isotherm (not shown). The maximum binding capacity of six calcium ions per L1 molecule was confirmed in dialysis experiments where different concentrations of $\mathrm{L} 1$ were dialysed against a constant $(0.2 \mathrm{mM})$ concentration of $\mathrm{CaCl}_{2}$. Extrapolation of protein concentration to zero suggest the binding capacity of six calcium ions per protein molecule (fig 3B).

The apparent dissociation constants, $K_{d \text { app }}$ calculated from the binding data are shown in table 1. A Scatchard plot of the parameters from the experiments gives a curve compatible with positive cooperative binding of $\mathrm{Ca}^{2+}$ to the protein (not shown).

DSC MEASUREMENT: EFFECTS OF DIFFERENT IONS AND CONCENTRATIONS ON THERMAL STABILITY

The series of thermograms in fig 4 show the effect of various calcium concentrations and different salts on the $\mathrm{L} 1$ denaturation enthalpy. The quantitative aspects of the effects are sum- 


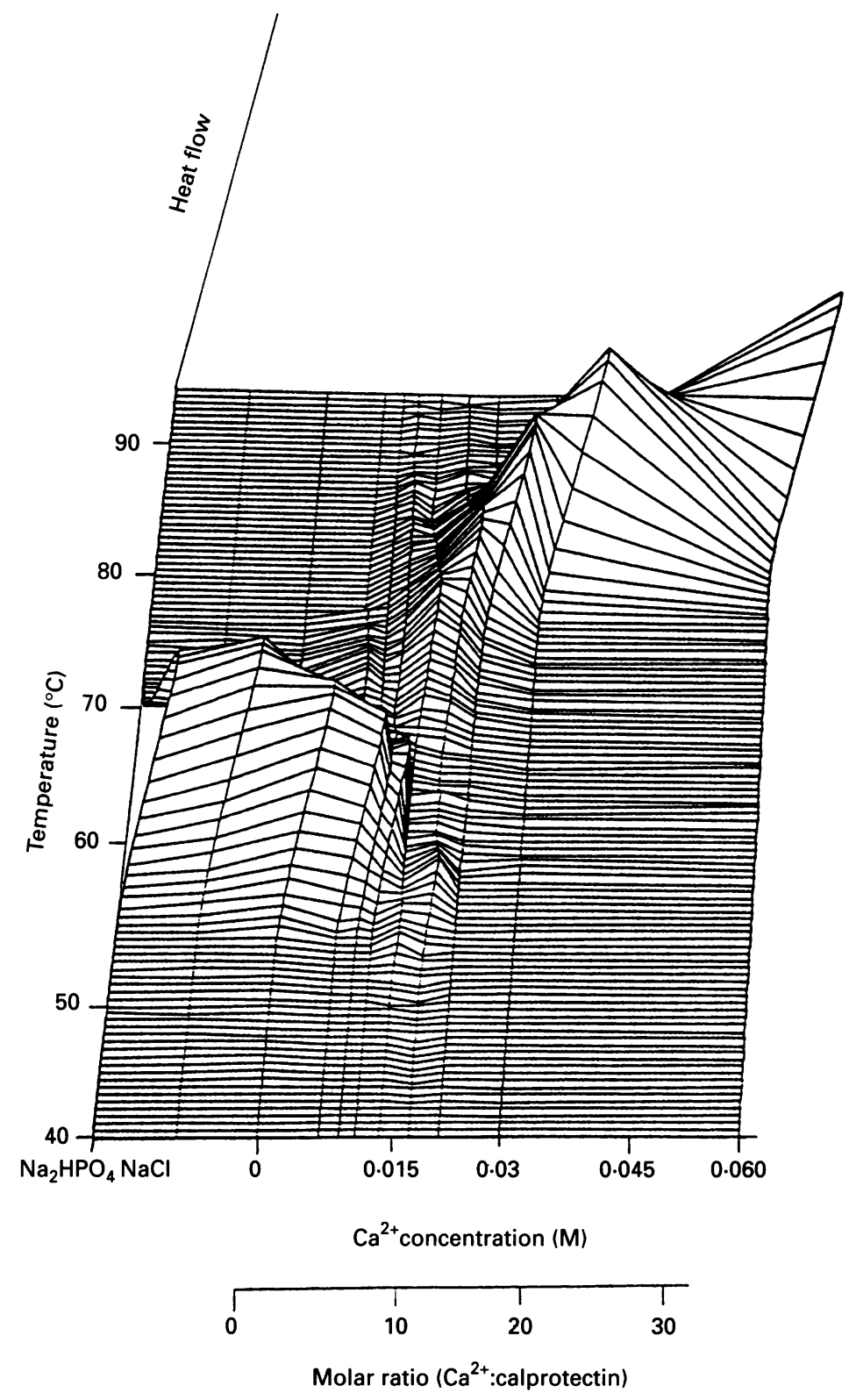

Figure 4 Effect of different cations and anions on the calorimetric thermograms of L1 (L1:60 mg/ml, $0 \cdot 1 \mathrm{M}$ Tris buffer, $\mathrm{pH} 8 \cdot 1$ ). The ionic strength was $0 \cdot 1 \mathrm{M}$ for the reference solutions and $0.28 \mathrm{M}$ for all others. The thermograms were obtained with $0.9 \mathrm{mg}$ of protein. enthalpy and T-onset increased. At the intermediate' calcium concentrations, the denaturation had a stepwise or biphasic/ multiphasic course. At the highest $\mathrm{Ca}^{2+}$ to protein ratio, the $\mathrm{L} 1 \mathrm{molecule}$ was significantly stabilised, with $\mathrm{T}_{\text {onset }}$ and $\Delta \mathrm{H}_{\text {app }}$ equal to $84 \cdot 3^{\circ} \mathrm{C}$ and $11 \cdot 8 \mathrm{~J} / \mathrm{g}$, respectively. Using this technique a $\mathrm{Ca}^{2+}$ to protein ratio of $>7$ was needed in order to induce the transition in $\mathrm{L} 1$ that led to a more heat stable form of $\mathrm{L} 1$. The whole transition was complete at a $\mathrm{Ca}^{2+}$ to protein ratio of $\approx 13$. However, some further change in stability was seen upon increasing the $\mathrm{Ca}^{2+}$ to protein ratio even further (fig 4 and table 2). An increase in ionic strength (from $0.1 \mathrm{M}$ to $0.28 \mathrm{M}$ ) did not alter $\mathrm{T}_{\text {onset }}$ or $\mathrm{T}_{\max }$ using either $\mathrm{NaCl}$ or $\mathrm{Na}_{2} \mathrm{HPO}_{4}$. A positive effect on $\Delta \mathrm{H}$ for the $\mathrm{L1}-\mathrm{NaCl}$ system is, however, possible. Phosphate ions had a minimal effect on all thermodynamic variables (fig 4).

EFFECT OF CALCIUM IONS ON SPECTRA OF L1 Figure 5A shows the far UV CD spectra of $\mathrm{Ll}$ with $0.6 \mathrm{mM}\left(\mathrm{Ca}^{2+}\right.$ to protein ratio $\left.=21\right)$ and without $\mathrm{Ca}^{2+}$. The spectra were rather similar. Minor differences were detected for wavelengths between 210 and $240 \mathrm{~nm}$; the lowest ellipticity was found in the presence of calcium at these wavelengths. Calculations of the secondary structure of $\mathrm{Ll}$ were attempted using Chang's model for protein structure. ${ }^{20}$ This model is not ideally suited for the $\mathrm{Ca}^{2+}$ saturated molecule, and the calculations on secondary structure suggesting that the $\mathrm{Ca}^{2+}$ saturated form of $\mathrm{L} 1$ has a higher $\beta$ sheet content should be interpreted with caution. Figure 5B shows the near-UV circular dichroic spectra $(250-350 \mathrm{~nm})$ of L1 with increasing concentrations of $\mathrm{Ca}^{2+}$ up to $0.60 \mathrm{mM}\left(\mathrm{Ca}^{2+}\right.$ to protein ratio $=21)$. There are striking and significant differences in the spectra between 275 and $305 \mathrm{~nm}$. The protein devoid of calcium has a positive peak value at $\approx 290 \mathrm{~nm}$ whereas the molecule saturated with calcium shows maximum negative ellipticity at $\approx 287 \mathrm{~nm}$. The bundle of curves between these extremes shows a conformational alteration with increasing calcium concentration.

UV spectra of the $\mathrm{Ll}$ protein dissolved in

marised in table 2. The protein dissolved in Tris buffer at $\mathrm{pH} 8 \cdot 1 \mathrm{had}$ an apparent enthalpy of denaturation $(\Delta \mathrm{H})$ of $8 \cdot 1 \mathrm{~J} / \mathrm{g}$. The denaturation started at $55.6^{\circ} \mathrm{C}$, with the maximum value at $62 \cdot 3^{\circ} \mathrm{C}$. When calcium ions were added to increasing concentrations, the

Table 1 Apparent dissociation constants calculated from data obtained from equilibrium dialysis experiments, varying the calcium concentration $\operatorname{var}\left(\mathrm{ca}^{2+}\right)$, and the L1 concentration (var L1)

\begin{tabular}{lll}
\hline & \multicolumn{2}{l}{ Dissociation constant $\left(K_{d a p p} \times 10^{-4} \mathrm{M}\right)$} \\
\cline { 2 - 3 } Binding $C A^{2+} / L 1$ & $\operatorname{Var}\left(\mathrm{Ca}^{2+}\right)$ & $\operatorname{Var}(L 1)$ \\
\hline 1 & $2 \cdot 75$ & $7 \cdot 80^{*}$ \\
2 & $2 \cdot 2$ & $3 \cdot 20$ \\
3 & $2 \cdot 26$ & $1 \cdot 84$ \\
4 & $1 \cdot 23$ & $0 \cdot 96$ \\
5 & $0 \cdot 67$ & $0 \cdot 36^{*}$ \\
6 & $0 \cdot 040^{*}$ & \\
\hline * Extrapolated or approximated values.
\end{tabular}

$0 \cdot 1 \mathrm{M}$ Tris buffer ( $\mathrm{pH} \mathrm{8 \cdot 1)}$ confirmed that the molecule contains near-UV absorbing chromophores. The curves had a peak at $279 \mathrm{~nm}$ and a minimum value at $250 \mathrm{~nm}$. The addition of $\mathrm{CaCl}_{2}$ had no significant effect on the UV recordings (spectra not shown). At $279 \mathrm{~nm}$ the protein solution ( $1 \mathrm{mg} / \mathrm{ml}, 1 \mathrm{~cm}$ light path) absorbs 0.693 . This gives an extinction coefficient $\mathrm{E}_{279}=2.53 \times 10^{4} \mathrm{M}^{-1} \mathrm{~cm}^{-1}$.

\section{ANALYTICAL ULTRACENTRIFUGATION}

Figure 6 shows the variations in the sedimentation coefficient with various calcium concentrations. When the protein is devoid of calcium it has a sedimentation coefficient, $\mathrm{S}_{20 \text {,ws }}$ of $2.04 \mathrm{~S}$. As the calcium concentration increases, the curve describing the sedimentation coefficient versus calcium con- 

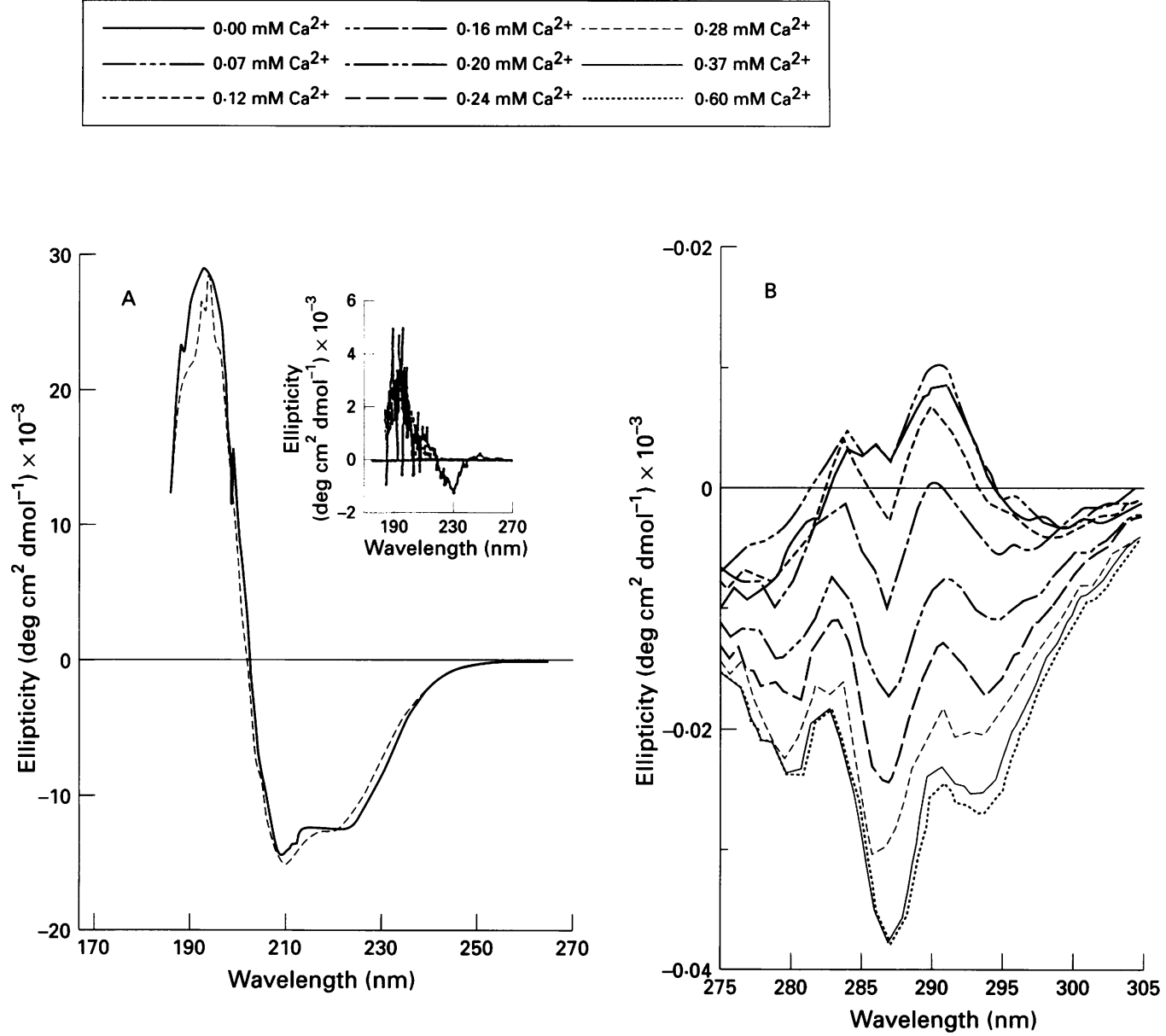

Figure 5 Circular dichroism spectra of $L 1$ in the presence and absence of calcium ions. (A) Far UV circular dichroic spectra of $L 1$ (solid line) (L1:1.3 mg/ml, $0.1 M$ Tris buffer, $p H$ 8.1) and $L 1+C a^{2+}$ (dashed line) (molar ratio L1: $\left.\mathrm{Ca}^{2+}=21\right)$. The inset shows the difference spectrum $(-)$ and the "standard deviation" (four determinations) spectrum (hatched area) for the same two systems. (B) Near UV circular dichroic spectra of L1 (L1:1.3 mg/ml, 0.1 M Tris buffer, $p H$ 8.1) with calcium concentration increasing up to $0.60 \mathrm{mM}$.

centration assumes a form of a sigmoid curve, reaching a maximum value of $3.47 \mathrm{~S}$ at $1.7 \mathrm{mM}$ calcium $\left(\mathrm{Ca}^{2+}\right.$ to protein ratio $\left.=12 \cdot 4\right)$. It can be seen from the figure that the transition using this technique started at a $\mathrm{Ca}^{2+}$ to protein ratio of 1.0 and seems to be finished at a ratio of 6 . In $0.55 \mathrm{mM}$ calcium $\left(\mathrm{Ca}^{2+}\right.$ to protein ratio $=$ 4) the analysis was also done at $68000 \mathrm{rpm}$ to increase the separation by reducing the diffusion. At 64 min two peaks were seen, suggesting inhomogeneity (results not shown). Thus the same protein solution was seen as homogeneous when devoid of calcium, as in- homogeneous at a particular calcium concentration, and then again homogeneous when saturated with calcium.

\section{MOLECULAR MASS DETERMINATIONS}

Molecular weight determinations performed with and without calcium in the buffers showed substantial difference in molecular weight. The molecular weight calculated from data obtained without calcium was $34 \mathrm{kDa}$; when the calcium concentration was $1.5 \mathrm{mM}\left(\mathrm{Ca}^{2+}\right.$ to protein ratio $=11)$ the obtained value was $73 \mathrm{kDa}$.

Table 2 Calorimetric data for the native to denaturated transition for $L 1$ at $p H 8 \cdot 1(0 \cdot 1 M$ Tris buffer) in the presence of different salts at constant ionic strength $(0 \cdot 28 \mathrm{M})$

\begin{tabular}{|c|c|c|c|c|c|}
\hline $\begin{array}{l}\text { Salt } \\
\text { added }\end{array}$ & $\begin{array}{l}\text { Concentration } \\
\text { (M) }\end{array}$ & $\Delta H(\mathcal{f} / g)$ & $\begin{array}{l}\text { Area ratio (low temp } \\
\text { peak to high temp peak) }\end{array}$ & $T_{\text {onset }}\left({ }^{\circ} C\right)$ & $T_{\max }\left({ }^{\circ} \mathrm{C}\right)$ \\
\hline $\begin{array}{l}\text { None } \\
\mathrm{CaCl}_{2} \\
\mathrm{CaCl}_{2} \\
\mathrm{CaCl}_{2} \\
\mathrm{CaCl}_{2} \\
\mathrm{CaCl}_{2} \\
\mathrm{CaCl}_{2} \\
\mathrm{CaCl}_{2} \\
\mathrm{CaCl}_{2} \\
\mathrm{Na}_{2} \mathrm{HPO}_{3} \\
\mathrm{NaCl}^{2}\end{array}$ & $\begin{array}{l}0 \\
0.075 \\
0.01 \\
0.012 \\
0.015 \\
0.0187 \\
0.0225 \\
0.03 \\
0.06 \\
0.06 \\
0.18\end{array}$ & $\begin{array}{c}8 \cdot 1(0.6) \dagger \\
8 \cdot 1(0.6) \\
8 \cdot 2(0.8) \\
8 \cdot 2(0.5) \\
9 \cdot 1(0.5)^{*} \\
10 \cdot 0(0.4)^{*} \\
10 \cdot 1(0.5)^{*} \\
10 \cdot 8(0.3) \\
11 \cdot 8(0.3) \\
8 \cdot 1 \\
9 \cdot 3\end{array}$ & $\begin{array}{l}\infty \\
\infty \\
\infty \\
\infty \\
1 \cdot 4 \pm 0 \cdot 6 \\
0 \cdot 2 \pm 0 \cdot 2 \\
0 \cdot 2 \pm 0 \cdot 2 \\
0 \\
0 \\
0 \\
0\end{array}$ & $\begin{array}{l}55 \cdot 6 \\
55 \cdot 8 \\
56 \cdot 7 \\
56 \cdot 7 \\
\text { nd } \\
\text { nd } \\
\text { nd } \\
80 \cdot 0 \\
84 \cdot 3 \\
57 \cdot 6 \\
56 \cdot 9\end{array}$ & $\begin{array}{l}62 \cdot 3 \\
62 \cdot 1 \\
62 \cdot 1 \\
62 \cdot 6 \\
75 \cdot 1 \\
79 \cdot 1 \\
82 \cdot 2 \\
84 \cdot 1 \\
88 \cdot 2 \\
88 \cdot 2 \\
63 \cdot 4\end{array}$ \\
\hline
\end{tabular}

* Encompasses a double peak 


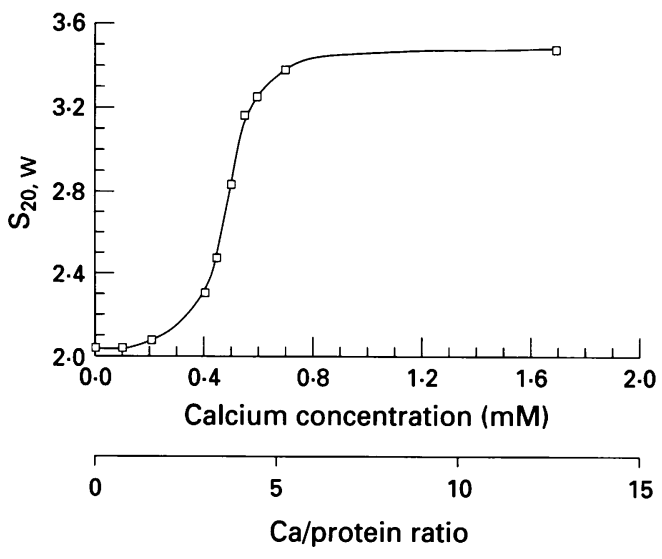

Figure 6 Variation in the sedimentation coefficient $S_{20, w}$ for L1 as function of calcium concentration. Protein concentration was $5 \mathrm{mg} / \mathrm{ml}$ in $0 \cdot 1 \mathrm{M}$ Tris- $\mathrm{HCl}$ buffer, $\mathrm{pH}$ 8.1. The rotor speed was $60000 \mathrm{rpm}$. See the text for comments on results for $0.55 \mathrm{mM}$ calcium.

\section{Discussion}

The results suggest a total of six calcium binding sites on each L1 molecule, which is in agreement with the presence of one classical and one modified EF-hand. ${ }^{58} \mathrm{~A}$ positive cooperative binding of $\mathrm{Ca}^{2+}$ was found, which has also been reported for other calcium binding proteins. ${ }^{21}$ The small differences in $K_{d \text { app }}$ determined by equilibrium dialysis with constant concentration of $\mathrm{Ll}$ or $\mathrm{Ca}^{2+}$ respectively are probably caused by different ionic strengths in the two systems. In our calculations we have used $36500 \mathrm{Da}$ as the molecular mass for the intact molecule. The differences between this value and molecular masses obtained by calculations from cDNA or other sources are about $2 \%$, which seems insignificant. In preliminary experiments the protein showed optimal binding at $\mathrm{pH} 7$, which is about 1 unit above its isoelectric point $(6 \cdot 3)$ when the protein will have a net charge. Tris-maleate buffers, $0 \cdot 1 \mathrm{M}$, will, however, render the Donnan effect negligible. ${ }^{22}$ Generally, it is expected that the effect of the ligand is seen at lower ratios of ligand to macromolecule, when the total concentration of the ligand binding molecule is high. The observations given in figs $5 \mathrm{~B}$ and 6 are compatible with the conclusion that the transition starts at a $\mathrm{Ca}^{2+}$ to protein ratio of about 2 .

The gradual increase in sedimentation during analytical ultracentrifugation (fig 6 ) is most likely to be due to a change in molecular weight caused by association of $\mathrm{L} 1$ molecules. The values of the sedimentation coefficients, 2.04 and $3 \cdot 47$, seem plausible for compact, largely spherical structures of molecular weights 34000 and 73000 , respectively, when the effect of protein concentration is taken into account. ${ }^{23}$ However, the exact shape of L1 is presently unknown.

The doubling of molecular mass, as shown by the low speed equilibrium technique, is taken as evidence that $\mathrm{L} 1$ will dimerise in the presence of low concentrations of calcium. Gel filtration experiments have confirmed this finding (data not shown). Other proteins also dimerise when saturated with calcium, ${ }^{24}$ but the ubiquitous calmodulin is reported to exist as a monomer. ${ }^{25}$

The true denaturation enthalpy reflects the breaking of various bonds in a protein molecule. ${ }^{26}$ Since calorimetric methods are equally as sensitive to bonds formed between neighbouring amino acids as they are to bonds formed between more distant amino acids, the differential scanning calorimetry technique can be very sensitive to changes in the tertiary structure of a protein. Figure 4 and table 2 suggest changes in the tertiary structure of $\mathrm{Ll}$ upon binding of $\mathrm{Ca}^{2+}$ since the only substantial changes were found in the near-UV circular dichroism.

An important finding was that the presence of calcium ions improves the thermal stability of the molecule to a considerable degree. The stabilising effect is evidenced both by increasing enthalpy, $\Delta \mathrm{H}$, and higher denaturation temperature. At intermediate $\mathrm{Ca}^{2+}$ concentrations $(7.5 \mathrm{mM}$ to $23 \mathrm{mM})\left(\mathrm{Ca}^{2+}\right.$ to protein ratio $=$ 4.7-14) the denaturation curves become quite complex, suggesting that different conformational $\mathrm{L} 1$ species may be present in the solution at the same time. The calorimetric technique also seems to respond late to the binding of $\mathrm{Ca}^{2+}$ when the effect of increased total protein concentration is considered. This suggests that the binding of $\mathrm{Ca}^{2+}$ is complete, or close to complete, before the protein is significantly stabilised. Our results are similar to those reported by Tsalkova and Privalov ${ }^{27}$ on calmodulin and troponin C. They showed that a stepwise melting process reflects the fact that different intramolecular bonds are broken in sequence because of major structural differences. They reported up to a $7 \%$ increase in melting enthalpy and a $47^{\circ}$ increase in denaturation temperature of calmodulin, while our figures were $26 \%$ and $31^{\circ}$ for L1. Anteneodo et al, ${ }^{18}$ who studied a sarcoplasmic reticulum calcium binding enzyme, reported a much smaller increase in stabilisation $\left(13.5^{\circ} \mathrm{C}\right)$ and no significant increase in denaturation enthalpy. This suggest that although stabilisation by $\mathrm{Ca}^{2+}$ is to be expected, the magnitude of the change in denaturation temperature and enthalpy varies substantially between different calcium binding proteins.

The changes in the spectral region 275-305 nm (fig 5B) can be caused by changes in the positions of the aromatic amino acids tyrosine and tryptophan. To a lesser extent the side chains of phenylalanine and histidine also contribute to the spectra. There were strong indications that the ellipticity of tryptophan residues may be sensitive to $\mathrm{Ca}^{2+}$ concentration because of the presence of the peaks at 284 and $292 \mathrm{~nm}^{28}$ in the $\mathrm{L1}-\mathrm{Ca}^{2+}$ system (fig 5B). It is also possible that tyrosine residues of $\mathrm{Ll}$ were sensitive to $\mathrm{Ca}^{2+}{ }^{29}$ The stepwise alteration of the different spectra may be due to gradual alterations in the groups or residues involved in, or affected by, the binding of calcium ions.

In conclusion, the data in fig 5B suggest that the binding of $\mathrm{Ca}^{2+}$ affects tryptophan and tyrosine residues. These amino acids are present in, or close to, the EF-hands in both the 
light and the heavy L1 chains. It should finally be pointed out that $\mathrm{L} 1$ differs from other calcium binding proteins with respect to changes in secondary structure; calmodulin and troponin $\mathrm{C}$ show an increase in the $\alpha$ helix content of $10 \%$ and $21 \%$ respectively, ${ }^{30}$ whereas $\mathrm{L} 1$ decreases its $\alpha$ helix content by about $5 \%$ upon exposure to $\mathrm{Ca}^{2+}$.

The protein concentrations used to obtain figs $5 \mathrm{~A}$ and $5 \mathrm{~B}$ are close to the protein concentrations used for the binding studies used in fig 3A. The data in figs $5 \mathrm{~A}$ and $\mathrm{B}$ are therefore interpreted as reflecting $\mathrm{Ca}^{2+}$ binding. The association process does not seem to lead to large changes in secondary structure (fig $5 \mathrm{~A}$ ).

Our findings suggest that L1 will associate to form a dimer, bind up to six calcium ions per molecule without severe structural changes, and thereby obtain a considerable increase in thermal stability.

All physical measurements reported here (analytical ultracentrifugation, circular dichroism, differential scanning calorimetry) point to a specific effect of $\mathrm{Ca}^{2+}$ on $\mathrm{L} 1$, in agreement with the data from equilibrium dialysis.

To comply with the demands of the different techniques, we used different protein-ligand concentrations. The resulting $\mathrm{Ca}^{2+}$ to protein ratios are, however, found under physiological conditions. The effects shown in this study are seen within the normal physiological range of calcium concentrations and may well be important in vivo. Others have suggested that different modfications of a protein molecule may have different functions. It is speculated that calmodulin may be recognised, in theory, as $4^{2}$ different conformations, ${ }^{8}$ a reasoning which also may be applied to L1. One must expect that the protein will change its conformation when moving from the cytoplasm to the extracellular milieu where it will be saturated with calcium.

The biological significance of increased temperature stability in the presence of calcium is unknown.

We thank engineer Eva Ruud at The Department of Biochemistry, University of Oslo, for performing the AUC and sedimentation calculations.

1 Steinbakk $M$, Naess-Andresen CF, Lingaas E, Dale I Brandtzaeg P, Fagerhol MK. Antimicrobial actions of calcium binding leucocyte $\mathrm{L} 1$ protein, calprotectin. Lance 1990;336:763-5.

2 Fagerhol MK, Dale I, Anderson T. Release and quantitation of a leukocyte derived protein $(\mathrm{L} 1)$. Scand $\mathcal{f}$ Haematol 1980;24:393-8.

3 Dale I, Fagerhol MK, Naesgaard I. Purification and partial characterization of a highly immunogenic leucocyte protein, the L1 antigen. Eur $\mathcal{F}$ Biochem 1983;134:1-6.

4 Andersson KB, Sletten K, Berntzen HB, Dale I, Brandtzaeg $\mathrm{P}$, Jellum E, et al. The leucocyte L1 protein: identity with the cystic fibrosis antigen and the calcium-binding MRP8 and MRP-14 macrophage components. Scand $f$ Immunol 1988;28:241-5.
5 Odink K, Cerletti N, Brüggen J, Clerc RC, Tarcsay L, Gerhards G, et al. Two calcium-binding proteins in infiltrate macrophages of rheumatoid arthritis. Nature 1987, 330:80.

6 Berntzen HB, Endresen GKM, Fagerhol MK, Spiechowicz J, Mowinkel P. Calprotectin (the L1 protein) during surgery in patients with rheumatoid arthritis. Scand $\mathcal{F}$ Clin Lab Invest 1991;51:643-50.

7 Berntzen HB, Fagerhol MK. L1, a major granulocyte protein; isolation of high quantities of its subunits. Scand $\mathcal{F}$ Clin Lab Invest 1990;50:769-74.

8 Lagasse E, Clerc RC. Cloning and expression of two human genes encoding calcium binding proteins that are regulated during myeloid differentiation. Mol Cell Biol 1988;8:240210.

9 Teigelkamp S, Bhardwaj RS, Roth J, Meinardus-Hager G, Karas M, Sorg C. Calcium-dependent complex assembly of the myeloic differentiation proteins MRP-8 and MRP 14. F Biol Chem 1991;266:13462-7.

10 Brandtzaeg P, Dale I, Fagerhol MK. Distribution of a formalin-resistant myelomonocytic antigen (L1) in human tissues. II. Normal and aberrant occurrence in various epithelia. Am f Clin Pathol 1985;87:700-7.

11 Gabrielsen T- $\varnothing$, Dale I, Brantzaeg P, Hoel PS, Fagerhol MK, Larsen TE, et al. Epidermal and dermal distribution MK, Larsen TE, et al. Epidermal and dermal distribution
of a myelomonocytic antigen (L1) shared by epithelial cells in various inflammatory skin diseases. $\mathcal{F} \mathrm{Am} \mathrm{Acad}$ Dermatol 1986;15:173-9.

12 Sander J, Fagerhol MK, Bakken JS, Dale I. Plasma levels of the leucocyte $\mathrm{L} 1$ protein in febrile conditions: relation to aetiology, number of leukocytes in blood, blood sedimentation reaction and C-reactive protein. Scand $\mathcal{F}$ Clin Lab Invest 1984;44:357-62.

13 Røseth AG, Kristinsson J, Fagerhol MK, Schjønsby $H_{\text {, }}$ Aadland E, Nygaard K, et al. Faecal calprotectin: a novel test for the diagnosis of colorectal cancer? Scand $\mathcal{F} \mathrm{Ga}$ stroenterol 1993;28:1073-6.

14 Gomori G. Histochemical demonstration of sites of choline esterase activity. Proc Soc Exp Biol Med 1948;68:354-8.

15 Pike E, Skuterud B. Methodological aspects of the determination of plasma binding of amitriptyline and nortriptyline. Nord Pharm Acta 1983;45:33-42.

16 Bennick $A$. The binding of calcium to a salivary phosphoprotein, protein A, common to human parotid and submandibular secretions. Biochem f 1976;155:163-9.

17 Harbitz O, Tenningen A, Martens H, Buer D. On-line aquisition, storage and interactive treatment of differential scanning calorimetric thermograms in a computer. Thermochim Acta 1984;72:201-4.

18 Anteneodo C, Rodahl AM, Meiering E, Heynen ML, Sennistera GA, Lepock JL. Interaction of dibucaine with the transmembrane domaine of the $\mathrm{Ca}^{2+}$-ATPase of sarcoplasmic reticulum. Biochemistry 1994;33:12283-90.

19 Van Del H, Haezebrouck P, Morozova L, Arico-Muende C, Dobson CM. Partially folded states of equine lysozyme. Structural characterization and significance for protein folding. Biochemistry 1993;32:11886-94.

20 Chang TC, Wu C-SC, Yang YT. Circular dichroic analysis of protein conformation: inclusion of the $\beta$-turns. Anal Biochem 1978;91:13-31.

21 Crouch TH, Klee CB. Positive cooperative binding of calcium to bovine brain calmodulin. Biochemistry 1980;19: cium to

22 Klotz IM. Ligand-protein binding affinities. In: Creighton TE, ed. Protein function - a practical approach. Oxford: IRI Press 1989.

23 Tanford C. Physical chemistry of macromolecules. New York: John Wiley and Sons, 1961:381

24 Nelson DJ, Hutton WC, Wells MA. Natural abundance carbon-13: magnetic resonance study of phospholipase A2(a) from Crotalus adamanteus. In: Wasserman $\mathrm{R} H$ et al, eds. Calcium-binding proteins and calcium function. New York: North-Holland, 1977.

25 Klee CB, Crouch TH, Richman PG. Calmodulin. Annu Rev Biochem 1980;49:489-515.

26 Privalov PL. Stability of proteins. Adv Protein Chem 1979; 33:167-241.

27 Tsalkova TN, Privalov PL. Thermodynamic study of domain organization in troponin $\mathrm{C}$ and calmodulin. $\mathcal{f} \mathrm{Mol}$ Biol 1985;181:533-44.

28 Venyaminov SY, Gogia ZV. Optical characteristics of all individual proteins from the small subunit of Escherichia coli ribosomes. Eur $\mathcal{F}$ Biochem 1982;126:299-309.

29 Blout ER. Polypeptides and proteins. In: Ciardelli F, Salvadori $\mathrm{R}$, eds. Fundamental aspects and recent developments in $O R D$ and $C D$. London: Heyden, 1971:353.

30 Cachia PJ, Van Eyk J, Ingraham RH, McCubbin WD, Kay CM, Hodges RS. Calmodulin and troponin C: a comparative study of the interaction of mastaparan and comparative study of the interaction of mastaparan and
troponin I inhibitory peptide (104-115). Biochemistry troponin I inhibitor 